\title{
Vitamin B17 Measurement
}

National Cancer Institute

\section{Source}

National Cancer Institute. Vitamin B17 Measurement. NCI Thesaurus. Code C74897.

The determination of the amount of Vitamin B17 present in a sample. 